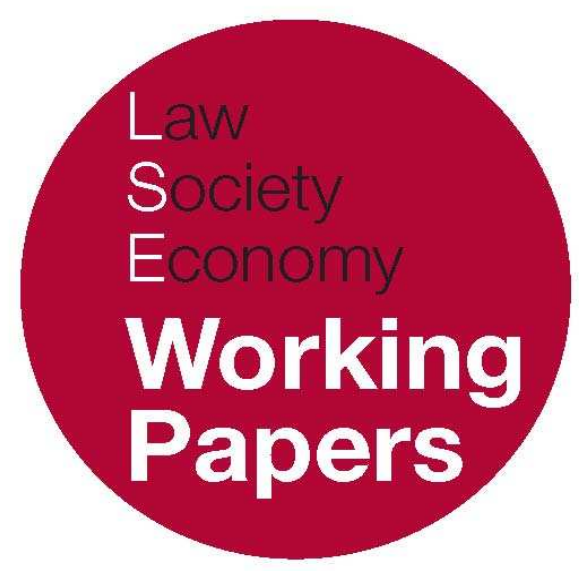

\title{
The Next 10 Year ECT Investment Arbitration: A Vision for the Future - From a European Law Perspective
}

\author{
Jan Kleinheisterkamp \\ LSE Law, Society and Economy Working Papers 7/2011 \\ London School of Economics and Political Science \\ Law Department
}

This paper can be downloaded without charge from LSE Law, Society and Economy Working Papers at: www.lse.ac.uk/collections/law/wps/wps.htm and the Social Sciences Research Network electronic library at: http://ssrn.com/abstract=1888201.

(C) Jan Kleinheisterkamp. Users may download and/or print one copy to facilitate their private study or for non-commercial research. Users may not engage in further distribution of this material or use it for any profit-making activities or any other form of commercial gain. 


\title{
The Next 10 Year ECT Investment Arbitration: A Vision for the Future - From a European Law Perspective
}

\author{
Jan Kleinheisterkamp *
}

\begin{abstract}
The interaction of investment treaty law with European law is a growing concern not only for policy makers but also for investors and arbitral tribunals, especially in the energy sector. This paper sketches the existing and potential legal problems between the regimes with the aim of drawing conclusions on the impact of those tensions on the future of the Energy Charter Treaty (ECT). In a first part, the paper discusses the problem of the compatibility of investment treaty law with European law in general that may require European member states to renegotiate their existing agreements. A second part is dedicated to the more controversial issues of the continuing applicability of intra-EU investment treaties, discussing their farreaching overlap with the protection afforded by European law and the resulting complications. Most of the previously discussed problems also arise under the Energy Charter Treaty, in addition to the specific complications that are analysed in a third part. The paper also outlines the consequences of the entry into force of the Lisbon Treaty and finishes with a summary and outlook of the general importance of these European developments for the future of the Energy Charter Treaty.
\end{abstract}

* Senior Lecturer at the Law Department of the London School of Economics; visiting professor at the University Panthéon Assas - Paris II; email: j.kleinheisterkamp@1se.ac.uk. Report for the SCC / ECT / ICSID Conference on '10 Years of Energy Charter Treaty Arbitration' (9-10 June 2011). 


\section{INTRODUCTION}

The entry into force of the Lisbon Treaty in 2009 has shaken the European landscape of investment treaty law. By redefining the European common commercial policy as including also foreign direct investments (Article 207 TFEU), investment treaty law is now, to a large extent, formally within the exclusive competence of the European Union (cf Articles 3.1(e) and 2.1 TFEU). This transfer of powers from the member states to the European Union has dramatic consequences. It is rather uncontroversial by now ${ }^{1}-$ and in any case accepted by the European member states ${ }^{2}$ - that the member states can no longer conclude new bilateral investment treaties without the previous empowerment by the Union and that future agreements on investments will be negotiated by or under the lead of the Union so as to substitute the existing BITs of the member states. The controversial part is the fate of the existing BITs with third countries in the transitional period until their effective substitution by EU agreements. The problems resulting from the new allocation of competences comes in addition to the complications relating to the continuing validity under EU law of BITs concluded with the Central and Eastern European countries which, with their accession to the European Union in 2004, have become 'intra-EU' BITs.

These problems all touch the Energy Charter Treaty (ECT) in a particular way. The ECT is, indeed, a child of the European Union. ${ }^{3}$ The idea for the ECT originated in a proposal of the Dutch government to the Council of the European Communities in June 1991 to create - in addition to the ECSC and Euratom - a European Energy Community. The aim was, in reaction to the end of the Cold War, to secure a market economy approach for the reconstruction and restructuring in the energy sector in the former communist countries. Leaving aside the gloss of another European Community, the European Commission elaborated the concept of the European Energy Charter, and the European Communities (EEC, ECSC, and Euratom) presented the proposal to the other countries of Central and Eastern Europe, of the USSR, and the non-European members of the OECD, which first led to the signing of the European Energy Charter in December 1991 and eventually to the ECT, signed in December 1994 -

\footnotetext{
${ }^{1}$ For the discussions about the interpretation of 'foreign direct investments' in the context of Articles 206 and 207, as to whether they cover only the pre-establishment market access aspects of foreign direct investments, see T. Eilmansberger, 'Bilateral Investment Treaties and EU Law' (2009) 46 Common Market Law Review 383, 389-396.

2 cf Council of the European Union, 'Conclusions on a Comprehensive European International Investment Policy' (3041st Foreign Affairs Council meeting Luxembourg, 25 October 2010) at <http://www.consilium.europa.eu/uedocs/cms_data/docs/pressdata/EN/foraff/117328.pdf>.

${ }^{3}$ For the following historic account, see the Final Act of the Energy Charter Conference, signed on 27 December 1994 in Lisbon at <http://www.encharter.org/fileadmin/user_upload/document/EN.pdf>.
} 
also in Lisbon. All old and (back then) future EU member states as well as the European Communities - now the EU - are parties to the ECT. ${ }^{4}$

The current problems arising from the tension between European law and the existing BITs of the member states, both intra-EU and extra-EU, therefore also all concern the ECT - although with the special twist that the EU itself is a party to it alongside the member states. The present paper sketches the problems of compatibility of the BITs and the ECT with EU law and offers an outlook into the resolution of these tensions in the future.

\title{
THE PROBLEMS OF COMPATIBILITY OF INVESTMENT TREATIES WITH EU LAW IN GENERAL
}

\author{
THE ENLARGEMENT OF THE EU AND THE PRISE DE CONSCIENCE
}

The problems of compatibility of investment treaties with EU law have first become apparent with the preparations of the accession of the Central and Eastern European countries to the European Community. In order to attract investments, most of the accession countries had previously concluded BITs both with the old EU member states as well as the other leading economies, such as especially the United States. In the context of the accession negotiations, the European Commission realised the potential limitations that those BITs could impose on the margin of manoeuvre of the accession states in their process of integrating the European acquis communautaire. The Commission approached the US government in 2003 in order to seek clarifications that US investors could not rely on these BITs for seeking remedies for the consequences that the European reforms in the accession countries would have. In September 2003, the Commission and the eight acceding countries signed a memorandum of understanding $(\mathrm{MoU})$ with the US government that aimed at ensuring the new member states could effectively apply the European legislation as of their accession in the most sensitive sectors. ${ }^{5}$ Although it is clear that this MoU is not binding in terms of international law, ${ }^{6}$ the Commission concluded that ' $[t]$ his

\footnotetext{
${ }^{4}$ See also Council and Commission Decision 98/181/EC, ECSC, EURATOM of 23 September 1997 on the Conclusion by the European Communities of the Energy Charter Treaty and the Energy Charter Protocol on Energy Efficiency and Related Environmental Aspects, 1998 OJ L 69/1.

${ }^{5}$ Understanding Concerning Certain U.S. Bilateral Investment Treaties, signed by the U.S., the European Commission, and acceding and candidate countries for accession to the European Union (22 September 2003) at <http://www.state.gov/s/1/2003/44366.htm> [hereafter: MoU]. On the MoU, see A. Radu, 'Foreign Investors in the EU - Which "Best Treatment"? Interaction between Bilateral Investment Treaties and EU Law' (2008) 14 European Law Journal 237.

${ }^{6} \mathrm{MoU}, \mathrm{n} 5$ above, Concluding Provisions: ' 1 . This Understanding constitutes a political arrangement [...] and is not an agreement binding under international law [...] 3. The Participants will act to complete the steps outlined in this Understanding to amend or interpret Acceding Countries' BITs with the United States as soon as possible [...]' The Annexes of the MoU spelled out the draft amendments or interpretation to be implemented on a bilateral basis.
} 
would exclude from the scope of the [US] BITs agriculture and audiovisual, but also transport, financial services, fisheries, energy, etc. ${ }^{7}$

The assessment of compatibility of BITs with EU law in the context of the US BITs also led the Commission shortly afterwards to take on the previous batch of accession countries (1995) on one of the main issues addressed (but not fully resolved) in the $\mathrm{MoU}$ - the restrictions on capital transfers (which are addressed below). The Commission requested Austria, Denmark, Finland, and Sweden to renegotiate their BITs in order to bring them in line with the Treaty of the European Union on this point. This eventually led to the well-known infringement procedures before the European Court of Justice in 2006 (excluding Denmark, which apparently managed to align its BITs) and resulted in the Austria, Sweden, and Finland being condemned in 2009 for breach of their obligation to cooperate because they refused to renegotiate their BITs. ${ }^{8}$ As of then, at the latest, it is clear that there is a serious potential issue with the compatibility of the member states' obligations arising from European law with those arising out of their BITs. And there can no longer be any doubt that - even before the transfer of exclusive competence for foreign direct investments to the EU - the member states have the obligation to bring their BITs in line with European law.

\section{The Member States’ obligation to Renegotiate their BITS}

In the above mentioned cases, the obligation to bring BITs in line with EU followed from the provision in (what is now) the Treaty on the Functioning of the European Union (TFEU) that addresses pre-accession obligations of member states under international law. Although pre-accession treaties remain in force, the member states have the obligation to take the necessary steps to eliminate incompatibilities with the European Treaties (Article 351 TFEU). This is actually merely a specification of the more general duty of loyal cooperation that is now enshrined in the Treaty of the European Union. Article 4(3) TEU establishes the same obligation for all member states regarding all their treaties, irrespective of whether they were concluded prior or after the accession:

The Member States shall take any appropriate measure, general or particular, to ensure fulfilment of the obligations arising out of the Treaties or resulting from the acts of the institutions of the Union.

The Member States shall facilitate the achievement of the Union's tasks and refrain from any measure which could jeopardise the attainment of the Union's objectives.

\footnotetext{
7 Press release by the Delegation of the European Union to the USA, EU/NR 59/03 (23 September 2003).

${ }^{8}$ CJ Cases C-205/06 (Commission v Austria) [2009] ECR I-1301; C-249/06 (Commission v Sweden) [2009 ECR I-1335; C-118/07 (Commission v Finland) [2009] ECR I-1301, I-1335 and I-10889.
} 


\section{EXAMPLES OF CONFLICT BETWEEN EU LAW AND BIT PROVISIONS}

The following is a short overview of some of the problematic issues of compatibility:

Capital transfer restrictions: As confirmed by the European Court of Justice (CJ), ${ }^{9}$ the unqualified capital transfer guarantees found in most BITs collide with the powers of the European Council to impose restrictions on the free transfer of capital to and from third countries in exceptional circumstances, notably to ensure reciprocity of treatment of financial operators in third countries as defined in a number of directives (Article 64(2) TFEU); in case of serious difficulties for the operation of the Economic and Monetary Union (Article 66 TFEU); and to allow freezing funds, financial assets, or economic gains relating to terrorist or similar activities (Article 75 TFEU). ${ }^{10}$ It seems that also the old member states have now remedied this issue since the $\mathrm{CJ}$ ruling. ${ }^{11}$

Performance requirements: EU quotas such as for certain agricultural products or the 'European content' in television broadcasting ${ }^{12}$ conflict with the prohibition of performance requirements found in numerous BITs. The same problem arises from EU procurement rules that require supplies and materials to be purchased with EU special funds to originate from the $\mathrm{EU}^{13}$ as well as $\mathrm{EU}$ rules requiring a carrier that seeks permission for inland waterway transport to use only vessels owned and controlled by nationals of an EU member state. ${ }^{14}$ In the $2003 \mathrm{MoU}$, the Commission and the US government, for the sake of retaining some 'policy space in strategic issues' 15 excluded certain sensitive areas - including hydrocarbons - from the obligation to grant national treatment or most-favourednation (MFN) treatment to foreign investors. ${ }^{16}$

\footnotetext{
${ }^{9}$ See $n 8$ above.

${ }^{10} \mathrm{It}$ is interesting to note that in its $\mathrm{MoU}$ with the Commission the US government accepted the restrictions relating to reciprocity of treatment of financial operators and, unsurprisingly, to terrorist activities, but not those relating to serious difficulties for the operation of the European EMU, presumably because of the losses suffered by US investors as a consequence of the economic and monetary turbulences in Argentina leading to its default in early 2002 (and triggering the biggest wave of BIT claims against one country in history).

${ }^{11}$ For such a re-negotiated clause, see the Protocol of 26 August 2009 to the French-Turkish BIT of 15 June 2006: 'The provisions of [Article 5 on the free transfer of capital] do not hinder the exercise in good faith by one Contracting Party of its international obligations as well as its rights and obligations resulting from its participation or association in a free trade zone, a customs union, a common market, an economic and monetary union or any other form of regional co-operation or integration.'

12 cf Council Directive 89/552/EEC of 3 October 1989, [1989] OJ L 298/23, art 4.

${ }^{13}$ Regulation (EC) 2110/2005 of the European Parliament and the Council of 14 December 2005, [2005]

OJ L 433/1, art 5. In their MoU, the participants noted that an EU measure requiring the use of EU goods or services may be satisfied by the use of goods and services of any country of the EU.

14 Council Regulation (EEC) 3921/91 of 16 December 1991, [1991] OJ L 373/91, art 2(1).

15 cf Radu, n 5 above, 252.

${ }^{16}$ Hydrocarbons, agriculture, and audio-visuals were excluded from both national and MFN treatment; the sectors excluded only from national treatment were securities, investment, or other financial services, fisheries, subsidies and transport (air carriers, inland waterways and maritime).
} 
Public policy exceptions: As also pointed out in the MoU, investors should be aware that companies established in the EU but owned or controlled by third country nationals (investment vehicles, typically Dutch) could, like any other European company, be subject to a different treatment than local companies for reasons of public policy, public security, or public health, and thus limited in their freedom of establishment and to provide services. ${ }^{17}$ Actually all fundamental freedoms of the internal market (ie also the free movement of goods, workers, and capital) are subject to such public policy exceptions in the Treaty, by which the member states reserved the right to suspend those freedoms to take regulatory measures for the sake of safeguarding national interests in exceptional circumstances even at the expense of discriminating against nationals of other EU member states. ${ }^{18}$ Accordingly, not only the application of the European directives coordinating the legal framework for such special treatment of (EU) foreigners, but also the national regulatory measures taken by the member states in the absence of harmonisation (who then act as trustees of the Union's interests) clash with the national or most-favoured-nation treatment guaranteed by the BITs.

State aid prohibitions and liberalisation: There is an inherent tension between the Central and Eastern European states' obligation under their BITs to honour their pre-accession concessions of special benefits to attract investors and their supervening obligation under the European Treaties not to distort competition in the Common Market through state aids. The problem is well illustrated by the claims (together exceeding $€ 800$ million) brought by Micula against Romania ${ }^{19}$ and - even more interesting in the present context because based on the ECT - by Electrabel, AES, and EDF against Hungary. ${ }^{20}$ The latter concern the termination of long-term power purchase agreements for electricity, the terms of which Hungary claimed to violate European state aid rules - as also confirmed by the European Commission decision ordering Hungary to recover that aid. ${ }^{21}$ The AES claim was dismissed on different ground; and the tribunal's majority - against Professor Stern's dissent on this point - did not find that the European state aid proceedings were relevant in this context. ${ }^{22}$ But if one of the other two tribunals

\footnotetext{
17 TFEU, art 53(2).

${ }^{18}$ For a short summary, see Communication of the Commission on Certain Legal Aspects Concerning Intra-EU Investments (97/C 220/06), [1997] OJ 220/15 at <http://eur-lex.europa.eu/LexUriServ/LexUriServ.do?uri=CELEX:31997Y0719(03):EN:NOT>.

${ }^{19}$ Micula v Romania, ICSID Case No. ARB/05/20 (claimant requests reinstatement of the legal framework prior to the revocation of certain financial incentives to invest in disfavoured regions or alternative $€ 450$ million in damages).

${ }^{20}$ Electrabel S.A. v Hungary, ICSID Case No. ARB/07/19; AES Sumnit Generation Ltd and AES-Tisza Erömü Kft v Hungary, ICSID Case No. ARB/07/22; EDF International S.A. v Hungary (ad hoc arbitration under UNCITRAL Rules).

${ }^{21}$ Commission Decision C (2008) 2223 final of 4 June 2008 on the State Aid Award by Hungary through Power Purchase Agreements in Case C 41/2005 at <http://ec.europa.eu/competition/elojade/isef/ case _details.cfm?proc_code $=3 \_C 41 \_2005>$.

22 AES v Hungary, n 20 above, Award of 23 September 2010, ๆ 10.3.15-10.3.19 at <http://ita.law.uvic. $\mathrm{ca} /$ documents/AESvHungaryAward.pdf $>$.
} 
were to follow the same line of reasoning, but awarded the claimed damages, this would put the existing investment protection system to a very serious test (provided that the CJ were to uphold the Commission's decision). Any payment on such an award would then itself constitute a violation by Hungary of European state aid rules since the damages would de facto re-allocate to the enterprise the forbidden economic benefit and thus perpetuate the illegal distortion of the market. Compliance with the award could - and should - prompt the Commission to initiate infringement procedures before the CJ. The AES v Hungary tribunal might have been right to state that it was not under an obligation to interpret the ECT in the light of the European state aid rules..$^{23}$ But any court of a European member state would be under the obligation to refuse recognition and enforcement of such an award because the hierarchy of norms is different for such a state court. Faced with the dilemma of having to breach either its country's obligations under international law ${ }^{24}$ or those under European law, a European judge is obliged to privilege the latter under the principle of the supremacy of the European Treaties.

Another example is the current case by the European Commission against Slovakia regarding priority electricity transmission rights. ${ }^{25}$ These were granted for 16 years by the Slovak state-owned network operator to a Swiss investor in exchange for paying over half of the construction costs of a electricity transmission line between Poland and Slovakia, based on a contract concluded prior to the EU's official decision to negotiate Slovakia's accession. Such priority access to the line would, according to the Commission, violate the nondiscrimination obligations imposed under EU legislation on the internal market in electricity. ${ }^{26}$ It is interesting to note that the Advocate General (AG) Jääskinen in his recent opinion came to the conclusion - albeit 'not without hesitation' - that the investor's rights arising under the Swiss-Slovak BIT against interference by the Slovak state were protected under Article 307(1) of the EC Treaty (now Article 351 TFEU) despite the fact that this result 'seems to sit at odds, at first glance, with the idea of market liberalisation that Directive 2003/54 aims to promote'. ${ }^{27}$ As regards the applicability of the ECT, the AG held obiter that:

[...] the detailed provisions contained in Directive 2003/54 and interpreted in detail in $V E M W^{28}$ cannot be overridden by the more general provisions

\footnotetext{
23 AES v Hungary award, ibid, 9 7.6.9.

${ }^{24}$ In the case of an ICSID arbitration: Articles 53 and 54 of the ICSID Convention, which obliges every contracting state to recognize and enforce ICSID awards without allowing any objections; otherwise the public policy exception of Article V(2)(b) of the New York Convention would be of avail.

${ }_{25}$ Pending CJ Case C-264/09, see <http://curia.europa.eu/jurisp/cgi-bin/form.pl?lang=en\&Submit= Rechercher\&numaff $=\mathrm{C}-264 / 09>$.

${ }^{26}$ Directive 2003/54/EC of the European Parliament and of the Council of 26 June 2003 concerning common rules for the internal market in electricity and repealing Directive 96/92/EC, [2003] OJ L176/37, arts 9, 20.

27 Case C-264/09, Commission v Slovakia, Opinion of AG Jääskinen of 15 March 2011, ๆ 109 at $<$ http://eur-lex.europa.eu/LexUriServ/LexUriServ.do?uri=CELEX:62009C0264:EN:HTML>.

${ }^{28}$ CJ Case C-17/03, VEMW, [2005] ECR I-4983.
} 
contained in the Energy Charter Treaty [...] EU energy law as it stands [...] cannot be considered as failing to achieve the standards required by the Energy Charter Treaty [...] Moreover, with respect to the enjoyment and protection of investments, the general level of the protection of fundamental rights provided by EU law affords protection to investors, which fulfils the obligations resulting from Articles 10(1) and 13(1) of the Energy Charter Treaty. ${ }^{29}$

Overlap with EU trade agreements with third countries: The EU had already negotiated, together with the Member States, mixed agreements with third countries which also cover matters of foreign direct investments, such as the Free Trade Agreements (FTA) with Chile (2002), ${ }^{30}$ the Cariforum (2008), ${ }^{31}$ and South Korea (2010). Furthermore, there are presently plans for negotiations of FTA with Canada and Singapore. These European agreements, which with their ratification, technically become part of European law, primarily concern the liberalisation of investments in services and industrial sectors, but may also address postestablishment rights of investors, including the possible restrictions that the parties to the FTA may impose. An example for this can be found - mirroring the problems of incompatibility with 'domestic' EU law - in capital transfer provisions in the FTA with Chile. They allow the contracting parties in case of 'serious balance of payments and external financial difficulties' to adopt 'restrictive measures with regard to trade in goods and in services and with regard to payment and capital movement, including those related to direct investments'. ${ }^{32}$ The BITs concluded by member states with Chile, however, contain unqualified guarantees of free transfer of capital. If an investor could challenge restrictions allowed by the FTA by invoking BIT provisions, this would undermine and upset the overall balance struck for this comprehensive regime for all economic activities covered by the FTA. Moreover, parallel regimes would also defeat the purpose of the Union's agreements to establish a level playing field for outbound investment by the economic actors from all European member states so as not to cause distortions on the European market by repercussion. For example, investors from Ireland or Slovakia could not escape the restrictions in the FTA with Chile since their home countries have not any BITs with Chile. Only a clarification - either in the European agreements or in general terms - that the EU agreements override the BITs insofar as they overlap would resolve this problem. ${ }^{33}$

\footnotetext{
${ }^{29}$ AG Opinion in Commission v Slovakia, n 27 above, 9 甲 101, 63.

30 [2002] OJ L 352/3.

31 [2008] OJ L 289/1.

32 EU-Chile FTA, art 195.

33 As a matter of international law (the Vienna Convention on the Law of Treaties (1969), the Member State BITs remain in force since they do not cover exactly the same subject matter as the EU agreements ( $\mathrm{cf}$ art 59), but their provision are not be applicable anymore to the degree that they are incompatible with the later EU agreement with the same third country, to which all Member States are also a party (cf art $30(3))$.
} 


\section{THE PARTICULAR PROBLEM OF INTRA-EU BIT'S}

The potential for conflict sketched above is not dependent on whether BITs are in force with third countries (extra-EU BITs) or with other member states (intra-EU BITs). This is illustrated by the use of investment vehicles such as in the notorious cases of CME / Lauder v Czech Republic that lead to parallel arbitrations in London (under the U.S.-Czech BIT) and in Stockholm (under the Dutch-Czech BIT) and a squarely contradicting outcome. ${ }^{34}$ The intra-EU situation, however, adds yet another layer of complexity and aggravates the potential for incompatibilities.

According to the European Commission, intra-EU BITs amount to an 'anomaly within the EU internal market'. ${ }^{35}$ In line with the general absence of North-North BITs at the global level, no two EU member states have ever concluded a BIT amongst each other. All of the approximately 190 existing intraEU BITs became intra-EU through accession, such as first those concluded by Germany with Spain and Greece before their respective accessions in 1981 and 1986. The overwhelming bulk of the intra-EU BITs were concluded as with the Central and Eastern European countries after the fall of the communist regimes to secure stable market conditions for West European investors - just like the multilateral ECT. This also hints the essential problem with intra-EU BITs: they were originally all 'pre-EU' BITs paving the way for outbound investments to the new neighbouring markets. Which raises, as with the already mentioned overlap with other EU trade agreements, the question of which instrument is to prevail. The framing of this question itself also hints at the underlying problem: prior to any termination of these BITs, which instrument is to prevail in terms of applicability and, moreover, applicable for whom?

\section{GENERAL INAPPLICABILITY OF INTRA-EU BITS?}

Both defendant member states and the European Commission as amicus curiae have forwarded the argument that the intra-EU BITs have ceased to be valid with accession and because of the primacy of EU law. This position has been rejected by arbitral tribunals, such as first in Eastern Sugar B.V. v The Czech Republic ${ }^{36}$ and recently in Eureco $\mathrm{v}$ The Slovak Republic, ${ }^{37}$ at least as regards the tribunal's jurisdiction. Indeed, the supremacy of EU law is an 'inner-EU' problem. It does not, as such, concern arbitral tribunals that derive their jurisdiction from the BIT, ie a treaty governed by public international law. As discussed in detail in Eureco, the

\footnotetext{
${ }^{34}$ Lauder (Ronald S) v Czech Republic (3 September 2001), (2002) 14:3 World Trade \& Arbitration Materials 35; CME Republic BV v Czech Republic (13 September 2001), ibid, 109. See for more detail J. D’Agostino and O. Jones, 'Energy Charter Treaty - A Step Towards Consistency in International Investment Arbitration?' (2007) 25(3) Journal of Energy \& Natural Resources Law 225, 226-230.

35 Eureko v Czech Republic, PCA Case No. 2008-13, Award on Jurisdiction, Arbitrability and Suspension, 26 October 2010, I 177 at <http://ita.law.uvic.ca/documents/EurekovSlovakRepublicAwardon Jurisdiction.pdf $>$.

36 Partial Award of 27 March 2007 at <http://ita.law.uvic.ca/documents/EasternSugar.pdf $>$.

${ }^{37} \mathrm{n} 35$ above.
} 
intra-EU BIT would only cease to be applicable for an arbitral tribunal under Article 59 of the Vienna Convention on the Law of Treaties of 1969 (VCLT) if in the absence of a clear intention to supersede the previously concluded BIT the posterior European treaties covered the same subject matter to a degree that 'the two treaties are not capable of being applied at the same time'. Even the European Commission has accepted that there is no such total incompatibility. ${ }^{38}$

\section{INAPPLICABILITY OF SPECIFIC BIT PROVISIONS}

Individual provisions of the intra-EU BIT, however, could become inapplicable if they are incompatible with the later concluded Treaty of Accession and thus the European Treaties according to Article 30(3) VCLT. In its award on jurisdiction, the Eureko tribunal rejected the Slovak Republic's and the Commission's arguments that the investor-state-arbitration provisions in the BIT would be incompatible with the European regime, pointing inter alia to the general use of commercial arbitration and the general possibility of arbitrators also applying mandatory EU law - albeit under the control of state courts. ${ }^{39}$ In the meanwhile, it transpires that another investment tribunal, seized with a claim brought by another insurance company against Slovakia on the same grounds, notably the policy change mandating the newly privatised investment sector to operate on a not-forprofit basis, is about to decline its jurisdiction. ${ }^{40}$ Indeed, the CJ will get a chance to give its opinion on the correctness of the finding of the Eureko tribunal: the OLG Frankfurt, seized by a request to set aside the award on jurisdiction, has requested the $\mathrm{CJ}$ for a preliminary ruling in this matter. ${ }^{41}$

What remains to be done is then the analysis of the compatibility of the individual substantive provisions of the intra-EU BITs - a task that would exceed the scope of this paper. It suffices to point out that, as sketched below, there is a considerable overlap of investor rights under intra-EU BITs and the ECT, on one hand, and investor rights under European law, on the other hand, and that the potential of incompatibility is significant, for the same reasons as in the extra-EU context: European investor rights come with much more, albeit qualified and strictly framed, 'policy space' than the BITs or the ECT. ${ }^{42}$ And it is difficult to conceive how the unqualified investment treaty standards can be applied at the same time as the qualified EU standards.

\footnotetext{
38 ibid, 9192.

39 ibid, ๆ 274, referring to CJ C-126/97, Eco Swiss China Ltd. v Benetton Int'l B.V., [1999] ECR I-3055.

40 L. Peterson, 'Arbitrators to Decline Jurisdiction Over $\$ 1$ Billion Arbitration Claim by Dutch Investor in Slovak Health Insurance Sector' LAReporter (17 May 2011) at <http://www.iareporter.com/articles/ 20110517_4>; referring to the PCA Case HICEE B.V. v Slovak Republic conducted under UNCITRAL Rules; see < http://www.pca-cpa.org/showpage.asp?pag_id=1334>.

${ }^{41}$ L. Peterson, 'German Courts Asked to Overturn Finding of Jurisdiction by Arbitral Tribunal in IntraEU Investment Dispute' LAReporter (13 January 2011) at <http://www.iareporter.com/articles/ 20110114_7>.

${ }^{42}$ See also Eureko, n 35 above, $\uparrow 226$.
} 
It was probably correct for the tribunal to state that the incompatibility of such wider protection with EU law 'is not a reason for cancelling Claimant's rights under the BIT' in the Eureko case, ${ }^{43}$ since it is, indeed, 'not for an arbitral tribunal to cancel rights created by a valid treaty in order to safeguard a State party against the possibility that it might one day decide to apply the treaty in a way that could violate its obligations under one or more other later treaties'. ${ }^{44}$ But it may be for the member states, either voluntarily or forced by the Commission and the CJ, to terminate the intra-EU BITs because of the important overlap and potential conflict with EU law, as shown in the following overview.

\section{THE GENERAL OVERLAP BETWEEN INTRA-EU BITS AND EUROPEAN LAW}

And that leads back to the nature of the intra-EU BITs as 'pre-EU' BITs: they were designed to afford the protection of EU investors in the former communist European countries in the absence of the protection afforded by the European treaties. The core of the regulation of the European internal market is the guarantee of national treatment (Article $18 \mathrm{TFEU}$ ) so as to allow every national of a member state to participate on the internal market without any discrimination on the basis of nationality. This general principle of non-discrimination finds its expression in the basic freedoms guaranteed to market participants and especially investors. The internal market comprises 'an area without internal frontiers in which the free movement of goods, persons, services and capital is ensured in accordance with the provisions of the Treaties' (Article 26 TFEU). Accordingly, investors may physically move and reside freely within the territory of the member states (Article 21 TFEU); they can move their capital freely within the internal market (Articles 63, 65 TFEU); they have the freedom to establish the companies they wish to use for their investments in any member state (Articles 49, 52 TFEU); their companies can provide their services across borders (Articles 56, 62, 52 TFEU); and their national employees can equally move freely (Article 45 TFEU).

All of these market freedoms are, of course, not unqualified. Member states are partially allowed to restrict these freedoms for the purposes of imperative requirements of public interest. Where these exceptions lead to disturbances on the level playing field of the internal market, the Union may use its competences to harmonise national legislation imposing restrictions on market freedoms. In any case, any regulatory legislation or administrative action based on these regulatory powers, be it by a member state or by the Union, is restricted by the test of proportionality, which ensures fair treatment by the adequate balancing private and public interest.

Moreover, any European investor enjoys the protection of fundamental rights, which were previously elaborated in the case law of the CJ in the light of the European Convention of Human Rights, and which are now laid down in the

\footnotetext{
43 ibid.

44 ibid, 9267.
} 
Charter of Fundamental Rights (CFR) as directly applicable law. 45 This includes the guarantee of personal liberty and security (Article 6 CFR); the freedom to pursue a freely chosen occupation (Article $15 \mathrm{CFR}$ ) and to conduct business (Article $16 \mathrm{CFR}$ ); the right to property, including the right to fair compensation in good time (Article $17 \mathrm{CFR}$ ); access to services of general economic interest (Article $36 \mathrm{CFR}$ ); and the right to good administration (Article $41 \mathrm{CFR}$ ) as well as access to effective justice and due process (Article $47 \mathrm{CFR}$ ).

Finally, this broad system of protection against state interference is supplemented by the CJ's case law based on the Francovich decision, ${ }^{46}$ which establishes the liability of member states or Union institutions for damages resulting from the violation of these individual freedoms and rights.

\section{CONSEQUENCES ARISING FROM THE OVERLAP}

This very rough overview of the existing system of protection of investments within the European internal market hints the degree to which the investor rights under EU law are co-extensive with those arising under the intra-EU BITs or the ECT. It also gives a flavour of the degree of potential conflict, given the higher degree of qualification and reservation of 'policy space' under EU law, adapted to the needs of regulating the Internal Market, and how the maintenance in force of the 'pre-EU' BITs after the accession is causing an 'anomaly within the Internal Market'. It needs to be seen what the $\mathrm{CJ}$ will hand down as a preliminary ruling to the OLG Frankfurt in the Eureko case. ${ }^{47}$ In any case, it is the Commission's declared intention to press for the termination of intra-EU BITs and has requested member states to act accordingly. ${ }^{48}$ Indeed, a number of member states especially the Central and Eastern European states hit by BIT claims - have already started to terminate some of their BITs with other European countries. ${ }^{49}$ Others, however, have taken the position that they prefer to keep their intra-EU BITs in force. It is quite predictable that the European Commission will bring procedures before the $\mathrm{CJ}$ for infringement of the duty of loyal cooperation in case of any refusal to terminate the intra-EU BITs.

\footnotetext{
45 TEU, art 6(1).

${ }^{46}$ Joined Cases C-6/90 and C-9/90, Francovich and Others v Italy, [1991] ECR I-5357.

${ }^{47}$ See $\mathrm{n} 41$ above.

48 cf L. Peterson, 'EC Asks Member-States to Signal by Year's End Whether They Will Terminate Their Intra-EU Investment Treaties; Spectre of Legal Actions Loom' LAReporter (23 October 2010) at <http://www.iareporter.com/articles/20101023_10/>; see also C. von Krause, 'The European Commission's Opposition to Intra-EU BITs and its Impact on Investment Arbitration' KluwerArbitationBlog (28 September 2010) at <http://kluwerarbitrationblog.com/blog/2010/09/28/theeuropean-commissions-opposition-to-intra-eu-bits-and-its-impact-on-investment-arbitration/ $>$. For the Commission's earlier plans in the same direction in 2006, see Eastern Sugar, n 36 above, $\mathbb{1} 126$.

${ }^{49}$ See, eg, L. Peterson, 'Czech Republic Terminates Investment Treaties in Such a Way as to Cast Doubt on Residual Legal Protection For Existing Investments' IAReporter (1 February 2011) at <http://www.iareporter.com/articles/20110201_13/>.
} 


\section{SOME ARGUMENTS REGARDING THE OBLIGATION TO TERMINATE BITS}

And it would not come as a surprise if the CJ were to follow the Commission in this respect. Some broader arguments can be derived from the statement of the Eureko tribunal on the respective scope of the regimes: 'The protections afforded to investors by the BIT are, at least potentially, broader than those available under EU law (or, indeed, under the laws of any EU Member State). ${ }^{50}$ The reason why BIT protection is 'at least potentially' broader is that they are framed in such broad and unqualified terms that it is not all that clear why and how arbitral tribunals should engage in a balancing of private and public interests that is equivalent to the mechanisms of judicial review of administrative acts under national laws and, by extension, under European law. This statement points at the very heart of the problem: why should investors from certain member states enjoy a greater degree of protection than that afforded by the European Treaties? Why should arbitral tribunals, in a purely intra-European context, not be bound to the same restrictions on judicial review as courts of the Union and the member states? That is, moreover, in the light of the fact that the European Treaties have put into place the well-tested procedural mechanisms that ensure that the European laws, establishing supra-national standards of protection of investments within the internal market, are they applied and interpreted autonomously, untainted by national parochial conceptions, and uniformly? And going beyond the substantive standards of protection: why should European investors in the Internal Market be allowed to short-cut the existing supranational judicial system of the CJ by using an alternative system of international arbitration?

The policy arguments brought forward against these questions are usually that the European judicial system still depends primarily on the judges of the member states who are at the same time Union judges when deciding disputes touching upon matters covered by EU legislation. And it would not be acceptable to investors operating in countries with persistent governance and corruption issues such as Romania and Bulgaria to have to exhaust local remedies before getting access to a preliminary ruling of the CJ. This argument seems to be all the more powerful when bearing in mind that if a host country's court of last instance refuses to submit a litigious question of interpretation of EU law to the CJ (for example by invoking the acte clair doctrine ${ }^{51}$ ), the investor is left to the mercy of its home country or the Commission accepting the troubles of bringing infringement procedures. But, after all, that is a general problem that every merchant, service provider, or worker faces. These systemic deficiencies of the local administrative and court structures arise equally under the Brussels I regime for civil and commercial disputes. It is not too far-fetched to compare the essence of the debate evolving around the intra-EU BITs to that of the West Tankers discussion, since both are based on the reluctance to accept the premise of mutual trust

\footnotetext{
${ }^{50}$ Eureko, n 35 above, $\mathbb{2} 245$.

51 CJ Case C-283/81, Srl CILFIT and Lanificio di Gavardo SpA v Ministry of Health, [1982] ECR I-3415, also referred to by the Eureko Tribunal, n 35 above, $\mathbb{} 282$.
} 
among and in the courts of all European member states postulated by the CJ. ${ }^{52}$ Seen from this perspective, the intra-EU 'mutual trust' problem is being addressed by the large European programmes for training judges and public servants in those countries to allow them to perform their role as part of the European administrative and judicial systems, to guarantee the European standards in their country as any other European member state. Keeping a parallel system of investment arbitration in place arguably undermines these efforts of institutional capacity building and could be considered as incompatible with the principle of mutual trust in the administration of justice in the European Union, ${ }^{53}$ at least in the present form provided for in the BITs, allowing for ICSID arbitration and the resulting exclusion of review of awards for their respect for European law.

In summary, there seem to be good reasons for the Commission to push for ensuring that EU law is the only regime governing investment flows within the European market and that the $\mathrm{CJ}$ is the only ultimate instance for interpreting and applying these rules. And it does not seem too far-fetched to expect the CJ to follow the Commission on this point.

\section{THE SPECIFIC COMPLICATIONS OF THE ECT IN THE EUROPEAN CONTEXT}

As already mentioned in the overview of the ECT's history, all European member states are parties to it. Accordingly, all the general problems of compatibility of BITs with EU law arise also under the ECT, such as for its unconditional capital transfer guarantees. ${ }^{54}$ Moreover, the problems of applicability or maintenance in force of intra-EU BITs equally arise, albeit in a somewhat more complex manner. The ECT, from the outset, was concluded as an instrument that would not only bind the 'old' EU member states vis-à-vis the later accession states, but also amongst each other. Put differently, the ECT was only partially a 'pre-EU' treaty; it was partially also, from the very beginning an 'original intra-EU' agreement even previous to the two accession waves. The ECT does not contain any limitations regarding its applicability among the 'old' EU member states. This 'original intraEU' element has not yet come into play. ${ }^{55}$ But this could soon change with the recent notification of intent by a group of investors in photovoltaic electricity from, inter alia, Germany, UK, and the Netherlands, to initiate arbitration

52 CJ Case C-185/07, Allianz SpA and Generali Assicurazioni Generali SpA v West Tankers Inc., [2009] ECR I$663, \uparrow 30$.

53 On this point see also the amicus curiae submission of the European Commission in Eureko, n 35 above, ๆ 185.

${ }^{54} \mathrm{ECT}$, art 14.

55 The $€ 1.4$ billion claim under the ECT by the Swedish energy company Vattenfall against Germany over problems with concessions for a power plant was settled, but, in any case, Sweden only acceded to the EU in 1995, ie after the conclusion of the ECT. 
proceedings against Spain under the ECT because of a revocation of beneficial tariff in the context of the austerity measures prompted by the financial crisis. ${ }^{56}$

Another layer of complexity is added by the fact that the ECT is a mixed treaty to which also the Union (as the successor of the European Community) itself is a contracting party. ${ }^{57}$ An unproblematic point is that, while the EU could well be a defendant in an ECT claim, a EU national or a company organised according to the laws of a European member state could not bring a claim against the Union, since they would not be an 'Investors of another Contracting Party' as required by Article 26(1) ECT. ${ }^{58}$

What is more complicated are questions such as the possibility of member states to 'disconnect' themselves from the ECT for the purposes of claims brought by EU investors so as to limit investor rights to the applicable EU law. ${ }^{59}$ The ultimately problematic point is how the European Union is to handle the dilemma of having created the ECT and now having to ensure its compatibility with EU law in relation to third countries and to deal with its continuing validity and applicability under international law also for intra-EU relations. A declaration of incompatibility by the $\mathrm{CJ}$ in a preliminary ruling in the Eureko procedure would facilitate things for the Commission as the pressure would be on the member states also to address the intra-EU element of the ECT. Otherwise, the Commission would have to recur to infringement procedures against member states that do not wish to touch the ECT. ${ }^{60}$ In any case, the elimination of parallel investment protection structures within the Internal Market in energy would require some form of general carve-out for intra-EU situations under the ECT. Such carve-out is ultimately necessary, even if the CJ were to declare intra-EU BITs or the ECT as incompatible with the European Treaties, since such a ruling would not be binding on arbitration tribunals established under the ECT - at least not if within the realm of the ICSID Convention that shields the award against any scrutiny by European jurisdictions. In order to create such a binding carve-out, the easier but apparently less certain way would be through inter se agreements of the member states, the effectiveness of which does not seem to be quite clear under the ECT; ${ }^{1} 1$ the more certain but also much more burdensome (and practically

\footnotetext{
56 See press release by White Owl Capital on 8 March 2011: 'International PV Investors Demand Compensation or Repeal for Retroactive Spanish PV Tariff Changes Under International Investment Treaty' at <http://www.presseportal.de/print.htx?nr=2004299>.

57 See also Council and Commission Decision 98/181/EC, ECSC, EURATOM of 23 September 1997 on the Conclusion by the European Communities of the Energy Charter Treaty and the Energy Charter Protocol on Energy Efficiency and Related Environmental Aspects, 1998 OJ L 69/1.

58 M. Burgstaller, 'European Law and Investment Treaties' (2009) 26(2) Journal of International Arbitration 181, 206-207.

59 ibid, 208-211.

60 The general - and not fully conclusive - recent remarks of the Advocate General on the ECT in relation to the European energy legislation could be taken as suggesting that, also for the ECT, the CJ could be inclined to uphold the priority of EU law over the ECT; see text accompanying $\mathrm{n} 29$ above.

${ }^{61}$ Burgstaller, $\mathrm{n} 58$ above, 210, pointing at ECT, art 26, which could be interpreted as prohibiting such a special inter se regime of exclusive application of EU law and exclusive jurisdiction of the CJ because that regime would be less favourable than the ECT, let alone because of the limited direct access by individuals to the $\mathrm{CJ}$.
} 
maybe too costly) way would be through a renegotiation of the ECT with the nonEU partners.

Clear is, however, that, whatever the difficulties, it could hardly be acceptable for the Commission in terms of consistency to leave the ECT untouched while obliging member states to bring their extra-EU BITs in line with EU law (or, in the alternative, to terminate them) and to terminate their intra-EU BITs. It remains to be seen in what direction the European Commission will push specifically for the ECT; but it seems probable that also the ECT's scope will eventually be affected by the EU context.

\section{THE CONSEQUENCES OF THE ENTRY INTO FORCE OF THE LISBON TREATY}

The entry into force of the Lisbon Treaty and the transfer of the power to regulate 'foreign direct investments' as a new part of the Common Commercial Policy into the exclusive competence of the EU does not really concern the intra-EU element of the ECT. Intra-EU investments are, by definition, not foreign direct investments. As regards the extra-EU element, the new exclusive competence will also not affect the ECT as such since the Union is already a contracting party. Accordingly, the Commission's draft regulation on transitional arrangements for investment agreements between member states and third countries ${ }^{62}$ is limited to 'bilateral' agreements, thus excluding from its scope the only multilateral agreement on investment, the ECT.

What does change is that the European member states lose their autonomy to renegotiate the ECT. The member states will thus probably not only have to accept the Commission's directions as to the future (elimination) of the intra-EU element of the ECT. It seems, at first sight, that they would also have to accept the Commission's dictate regarding the ECT's extra-EU element, at least insofar as regards the ECT provisions relating to foreign direct investments and, beyond that, those - according to the AETR case law ${ }^{63}$ - falling under the Union's exclusive competence for external relations in matters for which the Treaties conferred exclusive competence for the internal market. Such calls for changes can be expected to arise at least in the medium term when the Commission seeks to implement a new comprehensive European investment policy as outlined in its communication of July $2010 .{ }^{64}$ Contrasting the ECT with these standards for new European investment agreements could mean that also the ECT would have to be overhauled as its provisions do not sit comfortably with possible future standards

${ }^{62} \operatorname{COM}(2010) 344$ final at < http://trade.ec.europa.eu/doclib/docs/2010/july/tradoc_146308.pdf>.

${ }^{63}$ CJ Case 22/70, Commission v Council, [1971] ECR 263.

${ }^{64} \operatorname{COM}(2010) 343$ final at <http://trade.ec.europa.eu/doclib/docs/2010/july/tradoc_146307.pdf>. 
projected in the communication, such as greater detail of definition of the very broad substantive standards and, regarding procedural standards, more transparency (including open hearings, amicus curiae briefs, and publication of awards), and potentially even quasi-permanent arbitrators and / or appellate mechanisms. ${ }^{65}$

The ECT being a mixed agreement, the Union will still require the member states' consent for negotiating any such changes with the non-EU contracting parties to the ECT. This time, the problem of consent and potentially reluctant member states plays out at the European institutional level. In order to be able to negotiate any changes to the ECT, the Commission needs a mandate from the Council, which means that the Commission's proposal must get the endorsement of the qualified majority of member states votes. ${ }^{66}$ This means that reluctant states could prevent the Commission from negotiating changes to the ECT by brokering a blocking minority in the Council. Insofar as the proposed modifications aim to eliminate some conflict between the ECT and EU law, the Commission could then bring infringement procedures before the ECT against the recalcitrant member states so as to force them to agree to the mandate for bringing the ECT in line with EU law. Changes that aim to implement a new policy of the Union, in contrast, would be more difficult to bring about in the absence of general consent.

It clearly follows from Article 4(3) TEU that the member states have the obligation to cooperate in bringing their legislation and treaties into line not only with EU law but also EU policies. ${ }^{67}$ But new policies of the Union relating to foreign investments from or to third countries can, in principle, only be established by a decision of the European institutions; the Commission's communication alone or its request for mandate to implement new features in investment treaty law do not constitute yet policy of the Union. The failure to obtain the qualified majority vote in the Council would thus thwart the Commission's efforts to establish such a new policy. The situation could be different if the Commission first managed to obtain a series of mandates for including the sought features into bilateral EU agreements with third countries so as eventually to show a 'concerted strategy' for the inclusion of such features which could suffice for then forcing recalcitrant member states to fulfil their duty of cooperation as to abstain from blocking a renegotiation. ${ }^{68}$ In practice, this constellation is, however, quite unlikely to arise, and, once the Commission has consolidated its outline for a new EU investment policy, including certain concessions to the member states, it can be expected that the member states will accept moving towards new standards of investment protections also in the ECT.

\footnotetext{
65 ibid, 9-10.

66 TFEU, arts 207(3), 207(4), 218(2).

${ }^{67}$ See page 4 above.

${ }^{68}$ For the notion of a 'concerted strategy' as sufficing for showing a policy of the Union, see CJ Case C246/07, Commission v Sweden (PFOS), [2010] ECR I-0000, ๆๆ 76-94.
} 


\section{CONCLUSION AND OUTLOOK}

As regards its intra-EU dimension, it is unlikely that the CJ would come to the conclusion that the ECT is not applicable between member states, let alone because the ECT is the only investment treaty which from the beginning bound states that were originally members of the European Community (now Union) and because it was actually proposed and designed by the European Commission itself. In any case, its applicability by international arbitral tribunals would not necessarily be affected by such findings on incompatibility at the European level, although issues of recognition and enforcement of resulting awards in EU member states could be arising, such as in constellations as in $A E S \mathrm{v}$ Hungary. It can, however be expected that, given the Commission's strong determination to eliminate the parallelism of standards and recourses for investments inside the Internal Market, that also the intra-EU dimension of the ECT will be eventually be targeted by the Commission and may disappear if member states cooperate or are forced to cooperate by the CJ.

As regards the extra-EU dimension, one can expect that the Commission's ongoing review of existing BITs of the member states regarding their compatibility with EU law will eventually also prompt the need for re-mediating certain potential conflicts, such as regarding the unqualified capital transfer guarantees in the ECT, but potentially also others, as highlighted above. Again, it can be doubted that arbitral tribunals will feel compelled to interpret the ECT differently under the influence of EU law, but, depending on their procedural rules, they may want to bear in mind the possibility of having their award set aside or refused enforcement by courts of EU member states for violating certain fundamental EU mandatory laws. Conflicts with EU law can be expected to lead to an initiative by the European Commission to try to renegotiate the critical ECT provisions or to agree on an authoritative interpretation that can eliminate the potential for conflict.

Changes to the ECT that would incorporate innovative features resulting from a new European investment policy remain dependent on the consensus of the member states despite the fact that the European Union now has the exclusive competence for foreign direct investments. Following the Commission's communication 'Towards a Comprehensive European International Investment Policy' and the European Parliament's report thereon, ${ }^{69}$ the Commission is now exploring the contours of the new standards for such new European investment policies. Such features are likely to include: a higher degree of definition of substantive treaty standards; the limitation of choice of forum to ICSID only (despite the current obstacle of the EU's accession to the ICSID Convention) for

${ }_{69}$ Report on the Future European International Investment Policy (2010/2203(INI), adopted on 22 March 2011 at <http://www.europarl.europa.eu/sides/getDoc.do?type=REPORT\&reference=A7-2011$0070 \&$ language $=\mathrm{EN}>$. 
the purposes of institutional transparency and legitimacy; greater transparency at the levels of initiation of proceedings, access to documents, open hearings, amicus curiae briefs, and the publication of awards; greater consistency of outcomes through clearer rules of interpretation; and an appeal mechanism. It remains to be seen how much of this can eventually be implemented in the context of the ECT. 